\title{
KESALAHAN PENGGUNAAN BAHASA INDONESIA DALAM TEKS TERJEMAHAN MAHASISWA
}

\author{
Khoirun Nisa \\ E-mail: niesha.violet@yahoo.com \\ Imam Suyitno \\ E-mail: Imam.suyitno.fs@um.ac.id \\ Universitas Negeri Malang, Jalan Semarang 5 Malang
}

\begin{abstract}
ABSTRAK: Penelitian ini bertujuan mesndeskripsikan kesalahan penggunaan pilihan kata, bentukan kata, dan struktur kalimat dalam teks terjemahan mahasiswa Jurusan Sastra Indonesia Fakultas Sastra UM 2015. Penelitian ini menggunakan rancangan penelitian kualitatif dengan jenis penelitian deskriptif. Hasil penelitian ini menunjukkan bahwa mahasiswa banyak melakukan kesalahan pada penggunaan pilihan kata aspek ketidaksesuaian, penggunaan bentukan kata, dan struktur kalimat. Temuan tersebut membuktikan bahwa mahasiswa kurang memerhatikan penggunaan tata bahasa dalam menerjemahkan teks dari $\mathrm{BSu}$ menuju BSa (bahasa Inggris-bahasa Indonesia).
\end{abstract}

Kata Kunci: kesalahan, kaidah bahasa Indonesia, teks terjemahan

\begin{abstract}
This research aims to describe language error in college student Literature Department 2015 UM Faculty of Literature in the use of option word, formation word, and structure sentence. This research use qualitatif's method and use descriptive research type. This observational result points out that a lot of college student do mistake on using option word conformance aspects, use of formation word, and structure sentence. That finding proves that college student not paying attention on sentences struktur to translate of the teks from $\mathrm{BSu}$ to $\mathrm{BSa}$ (English language-Indonesian language).
\end{abstract}

Key word: error, Indonesian language rules, translation text

Kegiatan penerjemahan merupakan keterampilan yang sulit. Penguasaan terhadap bahasa Inggris saja sebagai Bsu atau bahasa Indonesia sebagai BSa tidak menjamin keandalan atau keterpercayaan terjemahan yang dihasilkan. Perbedaan gramatika dari kedua bahasa ini jika tidak dikuasai secara baik tentu saja akan mengakibatkan kesalahan, (Machali, 2000). Misalnya, kaidah frasa bahasa Indonesia adalah D(iterangkan) dan M(enerangkan), seperti siswa pandai yang 
berpadanan dengan intelligent student karena di dalam bahasa Inggris berlaku kaidah MD. Interferensi bahasa ibu (native language) juga ikut andil sebagai penyebab kesalahan dalam penerjemahan. Misalnya, seorang mahasiswa dalam menerjemahkan teks bahasa Indonesia ke dalam bahasa Inggris dipengaruhi oleh kaidah penulisan bahasa Indonesia, seperti expression yang ditulis dengan *ekpression.

Dalam penerjemahan, penerjemah perlu menguasai budaya dari 2 bahasa, yakni budaya bahasa dari teks yang diterjemahkan dan budaya bahasa untuk teks terjemahannya. Pernyataan ini jika dikaitkan dengan belajar bahasa mirip dengan penguasaan pelajar bahasa yang sedang mempelajari bahasa asing. Pelajar bahasa asing memiliki latar belakang budaya yang berbeda dengan latar belakang bahasa yang dipelajarinya (Suyitno, 2017). Karena itu, pelajar asing dalam mempelajari bahasa Indonesia harus melakukan strategi adaptasi dari budaya yang dimilikinya ke dalam budaya bahasa yang dipelajarinya.

Setiap bahasa memiliki sistemnya masing-masing. Dalam penerjemahan, tidak selalu dapat ditemukan padanan kata yang sama persis antara bahasa yang diterjemahkan dengan bahasa sasaran terjemahannya. Penerjemah perlu menemukan makna yang sedekat mungkin dari kata yang diterjemahkan tersebut ke dalam kata bahasa sasaran. Karena itu, dalam menganalisis naskah terjemahan tidak dapat digunakan model analisis kontrastif untuk membandingkan naskah bahasa sumber dengan naskah bahasa sasaran (Suyitno, 2008).

Makna bahasa merupakan satu tataran linguistik. Makna itu tidak lain daripada sesuatu atau referen yang diacu oleh kata atau leksem itu. Hanya perlu dipahami bahwa tidak semua kata atau leksem itu mempunyai acuan konkret di dunia nyata. Menurut Aminuddin (2011:19) bahasa memiliki sifat vagueness karena makna yang terkandung di dalam suatu bentuk kebahasaan pada dasarnya hanya mewakili realitas yang diacunya. Penjelasan secara verbal tentang aneka bunga mawar, tidak akan setepat dan sejelas dibandingkan dengan bersama-sama mengamati secara langsung aneka warna bunga mawar. Ambiguity berkaitan dengan ciri ketaksaan makna dari suatu bentuk kebahasaan. Berdasarkan uraian di atas, sangat tepat bila analisis kesalahan berbahasa digunakan sebagai suatu cara 
menganalisis kesalahan penggunaan bahasa Indonesia dalam teks terjemahan mahasiswa Jurusan Sastra Indonesia Fakultas Sastra UM 2015.

Penelitian sebelumnya dilakukan oleh Setyawan (2011) dengan judul Analisis Kesalahan Berbahasa Indonesia dalam Karangan Narasi pada Siswa Kelas IV SDN III Talang Kecamatan Sendang Kabupaten Tulungagung. Fokus penelitian ini yaitu kesalahan berbahasa pada tataran fonologi, morfologi, serta sintaksis. Pada tataran fonologi, peneliti memfokuskan penelitiannya pada kesalahan penulisan kata, penulisan huruf besar, penulisan tanda baca, tanda hubung, serta ketidakhadiran tanda hubung. Pada tataran morfologi, peneliti memfokuskan penelitiannya pada kata berimbuhan, penghilangan afiks ber- dan me-. Pada tataran sintaksis, peneliti memfokuskan pada kesalahan frasa dan kalimat. Sholikah (2013) melakukan penelitian dengan judul Analisis Kesalahan Berbahasa dalam Karangan tentang Perjalanan Siswa Kelas VIII MTsN Model Trenggalek. Hasil dari penelitian ini yaitu ditemukan 489 kesalahan ejaan, dua aspek pada kesalahan penggunaan pilihan kata yaitu leksikal dan gramatikal, kesalahan penggunaan kalimat tidak lengkap, tidak tepat, tidak logis, tidak hemat, dan tidak jelas.

Berdasarkan permasalahan di atas, dilakukan penelitian dengan judul Kesalahan Penggunaan Bahasa Indonesia dalam Teks Terjemahan Mahasiswa Jurusan Sastra Indonesia Fakultas Sastra UM 2015. Penelitian ini bertujuan mendeskripsikan kesalahan penggunaan pilihan kata, bentukan kata, dan struktur kalimat dalam teks terjemahan sehingga mahasiswa dapat memperbaiki kemampuan berbahasanya terutama dalam menulis.

\section{METODE}

Penelitian ini menggunakan pendekatan kualitatif. Pengkajian pada penelitian ini dilakukan secara mendalam dan terperinci guna memperoleh suatu deskripsi yang jelas terhadap kesalahan penggunaan pilihan kata, bentukan kata, dan sturktur kalimat dalam teks terjemahan mahasiswa Jurusan Sastra Indonesia Fakultas Sastra UM 2015. Oleh karena itu, penelitian ini merupakan penelitian deskriptif karena data yang dihasilkan dari peneliti bukanlah angka-angka, tetapi berupa kata-kata atau gambaran sesuatu (Djajasudarma, 1993:15). 
Data dalam penelitian ini adalah kesalahan penggunaan bahasa Indonesia, khususnya kesalahan penggunaan pilihan kata, bentukan kata, dan struktur kalimat dalam teks terjemahan mahasiswa jurusan Sastra Indonesia Fakultas Sastra UM 2015. Sumber data dalam penelitian ini adalah teks hasil terjemahan mahasiswa dari bahasa Inggris menuju bahasa Indonesia yang berjumlah 35 teks, sedangkan subjek dalam penelitian ini adalah mahasiswa offering A angkatan 2015 Jurusan Sastra Indonesia Fakultas Sastra UM.

Pada penelitian ini, data diperoleh dengan cara tes, yaitu tes menerjemahkan dari bahasa Inggris menuju bahasa Indonesia. Tes adalah serentetan pertanyaan atau latihan serta alat lain yang digunakan untuk mengukur keterampilan, pengetahuan inteligensi, kemampuan atau bakat yang dimiliki oleh individu atau kelompok (Arikunto, 2010:193). Oleh karena itu, instrumen yang digunakan dalam penelitian ini ada tiga macam, yaitu tes menerjemahkan berupa teks berbahasa Inggris beserta petunjuk dan perintah menerjemahkan, instrumen berupa tabel panduan analisis data, serta instrumen berupa tabel korpus data untuk analisis data.

Teknik analisis data dalam penelitian ini menggunakan lima tahap, yaitu (1) mengoreksi, yakni data yang sudah terkumpul dikoreksi hasil terjemahannya untuk mempermudah pengelompokan data; (2) klasifikasi, yakni mengelompokkan ketepatan penerjemahan, data yang sudah dikoreksi kemudian dibandingkan dengan hasil terjemahan yang benar; (3) kategorisasi, yakni membagi menjadi tiga kelompok: tinggi, sedang, dan kurang. Data tersebut dibagi menjadi tiga kelompo,k yaitu: (a) data yang mempunyai ketepatan penerjemahan tinggi, (b) data yang mempunyai ketepatan penerjemahan sedang, dan (c) data yang mempunyai ketepatan penerjemahan rendah; (4) identifikasi, yakni melakukan identifikasi kesalahan sesuai dengan masalah dalam penelitian, yaitu kesalahan penggunaan pilihan kata, bentukan kata, dan struktur kalimat; (5) penyajian data, yakni menyajikan hasil analisis pada setiap kelompok sesuai jenis kesalahan dan kemudian dilakukan penarikan kesimpulan. Keabsahan data digunakan untuk memperoleh data dan kesimpulan yang valid sebagai suatu karya ilmiah. Keabsahan data diperoleh melalui dua teknik, yaitu dengan kegiatan pengecekan ahli dan pengecekan teori. 


\section{HASIL}

Pada bagian ini dipaparkan data dan hasil temuan penelitian mencakup (1) data kesalahan penggunaan pilihan kata, (2) data kesalahan penggunaan bentukan kata, dan (3) data kesalahan penggunaan struktur kalimat dalam teks terjemahan mahasiswa Jurusan Sastra Indonesia Fakultas Sastra UM 2015.

\section{Kesalahan Penggunaan Pilihan Kata dalam Teks Terjemahan Mahasiswa Jurusan Sastra Indonesia Fakultas Sastra UM 2015}

Berdasarkan analisis data, ditemukan empat kesalahan penggunaan pilihan kata bahasa Indonesia dalam teks terjemahan mahasiswa Jurusan Sastra Indonesia Fakultas Sastra UM 2015. Kesalahan penggunaan pilihan kata tersebut meliputi aspek ketidaklaziman, ketidaksesuaian, ketidakcermatan, dan ketidakserasian.

Kesalahan penggunaan pilihan kata pada aspek ketidaklaziman banyak ditemukan pada hasil terjemahan yang mempunyai kelompok sedang dan rendah, sedangkan pada kelompok tinggi tidak banyak ditemukan kesalahan ketidaklaziman pilihan kata. Kesalahan ketidaklaziman disebabkan oleh penggunaan kata serapan dari bahasa Inggris. Selain itu, dalam kaidah bahasa Indonesia biasanya untuk penulisan kata serapan dicetak miring apabila diketik dan digarisbawahi apabila ditulis dengan tangan.

Kesalahan penggunaan pilihan kata pada aspek ketidaksesuaian ditemukan 7 kesalahan pada kelompok tinggi, 4 kesalahan pada kelompok sedang, 3 kesalahan pada kelompok rendah. Pilihan kata yang digunakan mengalami kesalahan karena tidak sesuai dengan konteks pemakainya.

Kesalahan penggunaan pilihan kata pada aspek ketidakcermatan ditemukan 4 kesalahan pada kelompok tinggi karena menggunakan kata yang jika dihapus tidak mengubah makna yang ingin disampaikan penulis. Ditemukan 4 kesalahan pada kelompok sedang dan rendah karena menggunakan kata yang bersinonim secara bersamaan yang mengakibatkan kemubadziran.

Kesalahan penggunaan pilihan kata pada aspek ketidakserasian ditemukan 1 kesalahan pada kelompok sedang dan 1 kesalahan pada kelompok rendah. 
Ketidakserasian pilihan kata disebabkan penerjemah atau penulis kurang bisa memilih kata yang sesuai dengan konteks atau situasi pemakainya,

\section{Kesalahan Penggunaan Bentukan Kata dalam Teks Terjemahan Mahasiswa Jurusan Sastra Indonesia Fakultas Sastra UM 2015}

Berdasarkan analisis data, ditemukan dua kesalahan penggunaan bentukan kata bahasa Indonesia dalam teks terjemahan mahasiswa Jurusan Sastra Indonesia Fakultas Sastra UM 2015. Kesalahan penggunaan bentukan kata tersebut meliputi kesalahan pembentukan kata berafiks dan kesalahan reduplikasi.

Kesalahan pembentukan kata berafiks ditemukan 2 kesalahan pada kelompok sedang dan rendah. Letak kesalahan pada peluluhan huruf setelah mendapat imbuhan di depan. Penulis atau penerjemah tidak bisa membedakan antara bentukan kata berafiks dan kata depan. Jadi, masih ditemukan 3 kesalahan penyamaan antara kata berafiks dan kata depan.

Kesalahan reduplikasi ditemukan 3 kesalahan pada masing-masing kelompok. Kesalahan terletak pada pengulangan kata dasar yang tidak konsisten, tidak menggunakan tanda hubung, dan kata yang jumlahnya lebih banyak tidak terjadi pengulangan.

\section{Kesalahan Penggunaan Struktur Kalimat dalam Teks Terjemahan Mahasiswa Jurusan Sastra Indonesia Fakultas Sastra UM 2015}

Berdasarkan analisis data, ditemukan empat kesalahan penggunaan struktur kalimat bahasa Indonesia dalam teks terjemahan mahasiswa Jurusan Sastra Indonesia Fakultas Sastra UM 2015. Kesalahan penggunaan struktur kalimat tersebut meliputi aspek kegramatikalan, ketidakhematan, dan ketidakpaduan.

Kesalahan kegramatikalan ditemukan 3 kesalahan pada semua kelompok. Letaknya kesalahannya, antara kalimat satu dengan kalimat lainnya tidak diberikan tanda titik, sehingga pembaca sulit menangkap pesan yang ingin disampaikan penulis. Kesalahan ketidakhematan dibagi menjadi dua, yaitu (1) penggunaan kata bersinonim dalam satu kalimat, dan (2) pemborosan kata yang seharusnya tidak diperlukan dalam satu kalimat. Pada kedua aspek 
ketidakhematan tersebut, masing-masing ditemukan 1 kesalahan. Kesalahan ketidakpaduan ditemukan 3 kesalahan. Kesalahan terletak pada kurang cermatnya dalam pemilihan kata, akibatnya gagasan makna dan bentuk bahasa yang digunakan tidak memiliki kepaduan.

\section{PEMBAHASAN}

Pada bagian pembahasan dipaparkan (1) kesalahan penggunaan pilihan kata, (2) kesalahan penggunaan bentukan kata, dan (3) kesalahan penggunaan struktur kalimat dalam teks terjemahan mahasiswa Jurusan Sastra Indonesia Fakultas Sastra UM 2015.

\section{Kesalahan Penggunaan Pilihan Kata dalam Teks Terjemahan Mahasiswa Jurusan Sastra Indonesia Fakultas Sastra UM 2015}

Kesalahan penggunaan pilihan kata terletak pada bagian ketidaklaziman pilihan kata, ketidaksesuaian pilihan kata, ketidakcermatan pilihan kata, dan ketidakserasian pilihan kata berdasarkan analisis data yang telah dilakukan. Mahasiswa banyak mengalami kesalahan ketika memilih kata yang tepat untuk menyusun maksud yang ingin disampaikan. Beberapa kata digunakan sesuai dengan apa yang mereka pikirkan tanpa melihat kata atau frasa yang digunakan tersebut sedap didengar (eufonik) atau tidak.

Ketidaklaziman dalam pemilihan kata berdasarkan analisis data yang telah dilakukan yaitu penggunaan kata yang sebenarnya kata tersebut ada tetapi sudah tidak digunakan dalam konteks tertentu. Selain itu, kesalahan terjadi juga dipengaruhi oleh penguasaan berbahasa penulis. Salah satu penggunaan kata yang tidak lazim terdapat pada teks hasil terjemahan mahasiswa dengan kode (S111/PKZ/1) terdapat istilah "and". Kata tersebut dianggap mengalami kesalahan karena dalam hal ini hasil terjemahan dari bahasa Inggris ke dalam bahasa Indonesia . Oleh karena itu, penggunaan istilah "and" dianggap mengalami kesalahan. Menurut Waridah (2014:60) bahwa bahasa tidak baku umumnya digunakan dalam komunikasi sehari-hari yang tidak bersifat resmi.

Selain ketidaklaziman pemilihan kata, ditemukan juga penyimpangan ketidaksesuaian pemilihan kata yang tidak sesuai dengan konteks. Pemilihan 
istilah menyangkut ketepatan memilih istilah yang sesuai dengan fungsi kata dalam kalimat. Ketidaksesuaian pemilihan kata dapat menyebabkan pembaca salah menginterpretasikan makna dari kalimat yang ditulis. Akan tetapi, pada teks hasil terjemahan mahasiswa ditemukan ketidaksesuaian pemilihan kata akibat ketidakcermatan penulis dalam memilih istilah yang sesuai dengan konteks. Kesalahan tersebut berakibat pada kesalahan logika kalimat. Pada kalimat mahasiswa dengan kode (S1-12/PKS/1) 'Belajar bahasa pendukung dapat dipengaruhi oleh banyak faktor'. Pilihan istilah pendukung tidak sesuai dengan konteks kalimat. Contoh tersebut tidak banyak ditemukan pada hasil terjemahan mahasiswa yang mempunyai tingkat ketepatan makna yang tinggi, sedangkan pada hasil terjemahan dengan tingkat ketepatan makna sedang dan rendah sering ditemukan kesalahan-kesalahan tersebut. Kekeliruan itu tidak akan terjadi jika mahasiswa lebih cermat memilih kata yang sesuai. Pemilihan kata harus memerhatikan ketepatan dan kecocokan (Nurchasanah dan Lestari, 2013:60).

Ketidakcermatan dalam pemilihan kata berdasarkan analisis data yang telah dilakukan yaitu penggunaan makna jamak ganda, menggunakan kata yang mempunyai kemiripan makna sehingga menyebabkan timbulnya kemubaziran. Selain itu, penyimpangan terjadi juga dipengaruhi oleh kurangnya ketelitian dari penulis. Salah satu penggunaan kata yang tidak cermat terdapat pada teks hasil terjemahan mahasiswa dengan kode (S1-10/PKC/3) terdapat istilah "sekali". Kata tersebut dianggap mengalami penyimpangan karena mengakibatkan timbulnya kemubaziran. Jika kata "sekali" dihilangkan, maka pesan yang ingin disampaikan penulis tidak akan berubah. Oleh karena itu, penggunaan istilah "sekali" dianggap mengalami penyimpangan.

Ketidakserasian dalam pemilihan kata berdasarkan analisis data yang telah dilakukan yaitu penggunaan kata yang tidak sesuai dengan konteks atau situasi pemakainya. Konteks dalam hal ini adalah kelaziman penggunaan kata tertentu dalam kelompok kata, sekalipun terdapat kata-kata lainnya yang bersinonim. Situasi adalah kelaziman penggunaan kata-kata tertentu yang penulisan atau pembicaraan sesuai dengan suasana dan status sosial pembaca atau pendengar. Salah satu penggunaan kata yang tidak serasi terdapat pada teks hasil terjemahan mahasiswa dengan kode (S1-6/PKR/2) terdapat istilah "berkaca". Kata tersebut 
dianggap mengalami penyimpangan karena penggunaannya tidak sesuai dengan konteks atau situasi pemakainya. Jika kata "berkaca" diganti dengan kata "tercermin", maka pemilihan kata akan terlihat serasi dengan konteks atau situasi pemakainya. Oleh karena itu, penggunaan istilah "berkaca" dianggap mengalami kesalahan.

\section{Kesalahan Penggunaan Bentukan Kata dalam Teks Terjemahan Mahasiswa Jurusan Sastra Indonesia Fakultas Sastra UM 2015}

Kesalahan penggunaan bentukan kata bahasa Indonesia terletak pada Kesalahan bentukan kata berafiks dan kesalahan kata berulang atau reduplikasi berdasarkan analisis data yang telah dilakukan. Mahasiswa banyak mengalami kesalahan pada bagian tersebut karena kurang memahami teori afiksasi dan reduplikasi secara baik dan benar. Kesalahan bentukan kata berafiks dan bentukan kata berulang atau reduplikasi jika dibiarkan akan membuat kesalahan-kesalahan lain pada bagian tersebut.

Terdapat kesalahan bentukan kata berafiks berdasarkan analisis data yang telah dilakukan. Kesalahan bentukan kata berafiks yang ditemukan adalah kekeliruan dalam penulisan kata yang mengalami pembentukan afiksasi. Kecermatan berbahasa antara lain pemilihan kata dan penggunaan kata. Sehingga dapat disimpulkan bahwa kesalahan penggunaan kata disebabkan oleh kurangnya kecermatan penulis. Kesalahan bentukan kata berafiks terdapat pada data dengan kode (S1-8/BKA/3) ada kata "mempengaruhi". Kata "mempengaruhi” mengalami kesalahan karena tidak sesuai dengan teori pembentukan kata, yakni jika kata dasar yang diawali dengan huruf $\mathrm{k}, \mathrm{t}, \mathrm{p}, \mathrm{s}$ mendapat imbuhan di depan (prefiks) maka huruf tersebut akan luluh. Tetapi, jika kata dasarnya berupa kluster (kl, pl, dan sebagainya), dan mendapat imbuhan di depan, maka huruf tersebut tidak luluh.

Terdapat kesalahan bentukan kata berulang atau reduplikasi berdasarkan analisis data yang telah dilakukan. Kesalahan bentukan kata berulang atau reduplikasi yang ditemukan adalah kesalahan pembentukan kata ulang yang tidak sesuai dengan KBBI yang menjadi patokan penulisan dalam bahasa Indonesia. Kesalahan bentukan kata berulang/reduplikasi terdapat pada data dengan kode 
(S1-10/BKR/) ada kata "kecendurangan-kecenderungan". Kesalahan yang terjadi akibat mahasiswa kurang memahami bentukan kata ulang yang benar sehingga mahasiswa menuliskan kata ulang dengan salah. Mahasiswa kurang memahami bentukan kata ulang yang tepat kemungkinan disebabkan oleh kurangnya minat baca, sehingga pembendaharaan kata yang dimiliki mahasiswa sangat terbatas. Tarigan (1989:213) menjelaskan bahwa faktor yang penting dalam pembangunan dan peningkatan kosakata adalah pengalaman yang kaya.

\section{Kesalahan Penggunaan Struktur Kalimat dalam Teks Terjemahan Mahasiswa Jurusan Sastra Indonesia Fakultas Sastra UM 2015}

Kesalahan penggunaan stuktur kalimat terletak pada kesalahan kegramatikalan kalimat, ketidakhematan kalimat, dan ketidakpaduan kalimat. Kesalahan kegramatikalan kalimat disebabkan mahasiswa kurang cermat dan kurang memahami teori gramatikal yang benar. Ketidakhematan dalam kalimat disebabkan mahasiswa terlalu banyak menggunakan kata-kata yang tidak diperlukan dalam satu kalimat. Ketidakpaduan dalam kalimat disebabkan mahasiswa kurang cermat menyusun kata dan frasa sehingga menghasilkan kalimat yang tidak padu. Berkaitan dengan temuan tersebut dilakukan pembahasan sebagai berikut.

Unsur gramatikal dalam kalimat harus diperhatikan karena memengaruhi pemahaman pembaca terhadap maksud dari kalimat tersebut. Kesalahan kegramatikalan dalam kalimat terdapat pada data dengan kode (S1-3/KG/1) "Mempelajari bahasa asing dapat dipengaruhi oleh beberapa faktor beberapa faktor tersebut dapat dikarenakan konteks sosial tempat belajar: kelas, interaksi...". Kalimat tersebut seharusnya bisa menjadi dua kalimat atau lebih. Letak kesalahannya, mahasiswa tidak memperhatikan intonasi final dan tetap menulis kata berikutnya. Pengembangan kalimat dikatakan salah apabila tidak memenuhi syarat gramatikal. Hal ini sejalan dengan Suparno (1991:5) yang berpendapat bahwa kalimat merupakan satuan gramatikal yang memiliki intonasi final. Pengembangan kalimat yang panjang atau pendek dikatakan benar apabila memenuhi kaidah. Selain itu, pengembangan kalimat harus mudah dipahami maksudnya. 
Kehematan kalimat maksutnya hemat dalam penggunaan kata, frasa yang dianggap tidak perlu. Penggunaan kalimat yang benar tidak harus panjang, tetapi harus bisa menyampaikan gagasan penulis. Kesalahan penggunaan kata juga memengaruhi kejelasan makna kalimat. Hal ini sejalan dengan Soedjito dan Saryono (2012:165) bahwa kalimat hemat adalah kalimat yang unsur-unsurnya tidak ada yang mubazir. Akan tetapi, terdapat kesalahan penggunaan struktur kalimat mahasiswa pada aspek kehematan. Adapun kesalahan kalimat mahasiswa dalam teks hasil terjemahan, yaitu penggunaan kata bersinonim dalam satu kalimat dan pemborosan kata dalam satu kalimat.

Pertama, penggunaan kata bersinonim dalam satu kalimat membuat kalimat salah pada aspek kehematan. Penggunaan kata bersinonim dalam satu kalimat dianggap salah karena kata yang digunakan tidak memiliki fungsi apapun. Salah satu kalimat yang memuat kata bersinonim dalam satu kalimat adalah kode (S1-2/KH/3) "Pelajar atau siswa menciptakan antara bahasa mereka dan menggunakan banyak sekali strategi”. Kesalahan kalimat tersebut adalah penggunaan kata 'pelajar' dan 'siswa'. Kata 'pelajar' sudah bermakna 'siswa'. Oleh karena itu. Penggunaan kata tersebut secara bersamaan justru menjadikan kalimat tidak efektif.

$K e d u a_{s}$ pemborosan kata dalam satu kalimat. Pemborosan kata maksudnya penggunaan kata yang tidak ada fungsinya dalam kalimat. Kesalahan struktur kalimat tersebut terdapat pada kalimat dengan kode (S2-3/KH/3) "Memberi perhatian khusus terhadap karakteristik siswa seharusnya merupakan sebuah kunci persoalan ketika merancang sebuah pembelajaran dalam tugas pembelajaran." Kesalahan kalimat tersebut terletak pada penggunaan kata 'seharusnya'. Kata tersebut sebenarnya tidak diperlukan dalam kalimat itu karena akan membuat kalimat menjadi tidak hemat.

Kepaduan kalimat perlu diperhatikan karena jika kalimat tidak memiliki kepaduan, maka kalimat tersebut akan mengalami kekaburan makna. Ketidakpaduan kalimat terdapat pada kalimat dengan kode (S1-5/KD/2) "Belajar dapat terlibat aktif karena proses kemahiran dan memanfaatkan berbagai strategi yang dapat diklasifikasi sebagai meta kognitif, kognitif, dan sosio afektif." Kalimat tersebut tidak padu karena tidak adanya kesatuan makna dalam satu 
kalimat tersebut. Hal ini dikarenakan kurang cermat dalam pemilihan kata akibatnya gagasan makna dan bentuk bahasa yang digunakan tidak memiliki keserasian.

\section{PENUTUP}

\section{Simpulan}

Berdasarkan hasil analisis dan pembahasan diperoleh tiga simpulan penelitian sebagai berikut.

Pertama, kesalahan penggunaan pilihan kata yang meliputi (1) aspek ketidaklaziman ditandai munculnya kata berbahasa Inggris dalam teks terjemahan bahasa Indonesia, (2) aspek ketidaksesuaian ditandai dengan penggunaan kata yang tidak sesuai, (3) aspek ketidakcermatan ditandai dengan penggunaan kata yang mubadzir, dan (4) aspek ketidakserasian ditemukan kata yang tidak serasi dengan konteks pemakainya.

Kedua, kesalahan penggunaan bentukan kata yang meliputi (1) aspek afiksasi ditandai dengan kesalahan peluluhan huruf yang mendapat imbuhan di depan kata, dan (2) aspek reduplikasi ditandai dengan kesalahan pengulangan kata dasar yang kurang konsisten.

Ketiga struktur kalimat yang meliputi (1) aspek kegramatikalan ditandai dengan tidak memberikan tanda titik pada kalimat dan menggabungkan dua kalimat secara langsung, (2) aspek ketidakhematan ditandai dengan penggunaan dua kata yang bersinonim secara bersamaan, dan (3) aspek ketidakpaduan ditandai dengan kalimat yang memiliki makna ambigu dan sulit dipahami.

\section{Saran}

Berdasarkan simpulan, ada beberapa saran yang dapat diberikan oleh penulis. Beberapa saran dari penulis tersebut telah dipaparkan dalam beberapa poin berikut.

Pertama, kepada dosen pengampu matakuliah Bahasa Inggris Terjemahan disarankan untuk memberikan arahan kepada mahasiswa terkait aspek ketidaklaziman dalam pemilihan kata ketika mahasiswa menerjemahkan teks dari 
Bahasa Inggris ke Bahasa Indonesia karena dari hasil penelitian masih banyak ditemukan kesalahan pada aspek tersebut.

Kedua, kepada peneliti selanjutnya disarankan untuk lebih memperluas sumber datanya karena dalam penelitian ini hanya mengambil data dari offering A Jurusan Sastra Indonesia angkatan 2015. Dengan mengambil data yang lebih luas dan pada angkatan yang berbeda, maka akan dihasilkan penelitian penggunaan kaidah Bahasa Indonesia yang lebih baik.

\section{DAFTAR RUJUKAN}

Aminuddin. 2011. Semantik (Pengantar Studi Tentang Makna). Bandung: Sinar Baru Algensindo.

Arikunto, S. 2010. Prosedur Penelitian: Suatu Pendekatan Praktik. Jakarta: Rineka Cipta.

Djajasudarma, F. 1993. Metode Linguistik: Rancangan Metode Penelitian dan Kajian. Bandung: Penerbit PT Eresco.

Machali, Rochayah. 2000. Pedoman bagi Penerjemah. Jakarta : Grasindo.

Nurchasanah. \& Lestari, I. 2013. Dasar-Dasar Menulis Karya Ilmiah: Bahasa Indonesia Keilmuan. Malang: Aditya Media Publishing.

Soedjito \& Saryono, Dj. 2012. Tata Kalimta Bahasa Indonesia. Malang: Aditya Media Publishing.

Suparno. 1991. Ciri Struktural Kalimat Bahasa Indonesia. Malang: IKIP Malang.

Suyitno, Imam. 2017. Reconstruction of Basic Knowledge on Learning BIPA for Developing Professionalism of BIPA Teachers, dalam IJRDO-Journal of Educational Research, Volume-2, Issue-2, February,2017, Paper-17.

Suyitno, Imam. 2008. Dimensi Teoretis dan Metodologis Belajar Bahasa Asing. Malang: Cakrawala Indonesia

Tarigan, H. G. 1989. Pengajaran Kosakata. Bandung: Angkasa.

Waridah, E. 2014. Pedoman Kata Baku dan Tidak Baku Dilengkapi Ejaan Yang Disempurnakan (EYD). Bandung: Ruang Kata. 